\title{
The Implication of Judicial Review for the National Law Development in Indonesia
}

\author{
Riris Ardhanariswari \\ Universitas Jenderal Soedirman \\ ririsardhana@gmail.com
}

\author{
Muhammad Fauzan \\ Universitas Jenderal Soedirman \\ fauzanhtn@yahoo.co.id
}

\begin{abstract}
Article 24 C paragraph (1) and (2) of the 1945 constitution amendment result outlines some of the authorities to be doneby the constitutional court. Judicial review by the Constitutional Court may result in a law being amended, either paragraph, chapter, chapter or whole, because it is the Constitutional Court's decision to declarewhether or not a law isin contrast withthe 1945 constitution; thus, when it happens, the law is declared invalid or does not exist. The further implications of a judicial review are not only to amend and modify a law but also contribute to a better national development framework that fits the soul and spirit of the proclamation. The Constitutional Court as a "supreme body" has a huge influence on this.
\end{abstract}

Keywords: Judicial Review, Implication, National Law Development

\section{INTRODUCTION}

The amendment of the 1945 Constitution provides a new color in the constitutional system. One of the reasons in the 1945 Constitution is article 1 paragraph (2) which reads "sovereignty is in the hands of the people and implemented through the Constitution".This provision implies that the people's sovereignty is no longer fully exercised by the people's consultative assembly, but is conducted in accordance with the provisions of the constitution. In addition, the amendment of the 1945 Constitution has labored to a state institution that serves as a guardian and interpreter of the constitution, namely the presence of the Constitutional Court.[1]

Conceptually, the idea of establishing a Constitutional Court is to organize a judiciary to enforce law and justice. Besides, it is also to adjudicate the first and and final levels of which the verdict is final in terms of examining the law against the 1945 Constitution of the state of the Republic of Indonesia, and other authorities it possesses.[2]

As the sole interpreter of the constitution, the Constitutional Court in its development by some law enforcers is feared to become an institution that has a super authority. Particularly in settling cases related to the authority it possesses, the Constitutional Court can unilaterally interpret the constitution without any question. Furthermore, the decision produced by the Constitutional Court is final and binding, so that when any party who feels aggrieved by the decision of the Constitutional Court can not make other legal efforts.

The decision of the Constitutional Court will certainly affect the national development of Indonesia, especially in the national law development. This is what the authors find interesting to investigate further. For that reason, is it necessary to conduct research on the implications of the judicial review of the national law in Indonesia?Based on that background, thus the problem isformulated as follows: What is the implication of the judicial reviewon the development of national law in Indonesia?

\section{METHOD}

The approach method used in this research is the normative juridical approach, because the problem to be investigated is related to the authority of the Constitutional Court in conducting judicial review of the law against the Constitution and its implications for the development of national law in Indonesia.

The specification of this research is descriptive analysis with the object to be studied, that is connectedto the implication of judicial review to national law development in Indonesia. The data used in this research is secondary data.

\section{RESULT}

\section{The Development of Judicial Review in Indonesia}

The establishment of the Constitutional Court marks a new era in the judicial power system in Indonesia. The idea of the importance of a Constitutional Court has emerged in the history of the Indonesian state administration prior to the independence. At the time of the drafting of the Constitution of the Procurement Entity of Indonesian Preparatory Enterprises. The idea of the necessity of judicial review, especially thatagainst the Constitution, reemerged at the time of the discussion of the Judicial Power Law Bill, which was subsequently stipulated as Law 
Number 14 Year 1970 on the Principles of Judicial Power. Then, at the time of the discussion of the amendment of the 1945 Constitution in the reformation era, opinions on the importance of the Constitutional Court reappeared. The presence of the Constitutional Court through the third amendment of the 1945 Constitution in the annual session of the People's Consultative Assembly (2001) has a strong constitutional basis. That is, the existence, position, authority, obligation, and composition of the judges of the Constitutional Court are strictly regulated in the 1945 Constitution.

The existence of the Constitutional Court at the same time to maintain the implementation of a stable state government, and also a correction of the past state administrative experience that resulted from a double interpretation of the Constitution. The Constitutional Court as one of the judicial authorities is expected to be able to restore the image of the judiciary in Indonesia as a trustworthy free judicial power in upholding the law and justice.[3]

\section{The Implications of Judicial Reviewonthe Development of National Law in Indonesia}

National development is a series of sustainable development efforts covering all aspects of community life, nation and state, to carry out the task of realizing national goals as formulated in the Preamble to the 1945 Constitution.[4] Legal development can not be separated from national development in Indonesia. Legal development is apart of national development; legal development will also support development in other fields.[5]

One thing that must be considered in implementing the development of law is that law must be understood and developed as a unity of system in which it comprises institutional, legal material, and legal culture elements. National Law is a legal unity that is built to achieve the purpose of the state that comes from the philosophy and constitution of the state. In both cases it contains the objectives, foundations, and ideals of the Indonesian state.[6]

A democratic state of law can be formed if it consistently consists of three pillars: rule by law, enforcement of human rights, and access to justice. In the context of Indonesia the three pillars must be bound by Pancasila as the ideology of Indonesia.[7]

Mahfud MD formulates that the politics of the law is the direction or official line that is used as the basis and the way to create and implement the law in order to achieve the goals of the nation and state. Political law is also an attempt to make the law as a process of achieving state goals. Legal politics contains two inseparable sides as the direction of law making or legal policy of state institutions in the making of law as well as a tool to assess and criticize whether a law is made in accordance with the legal policy framework to achieve the state goal or not.[8]-[9]
Hereinafter, it is emphasized that the discussion of legal politics to achieve the objectives of the state with a national legal system includes at least the following matters: [10]

1. The objectives of the country or the people of Indonesia are desirable as the political orientation of the law, including the exploration of the basic values of the purpose of the state as a legal political guide.

2. The national legal system which is necessary to be achieveddepends on the goal and factors that influence it.

3. Planning and frame of mind in the formulation of legal policy.

4. The contents of national law and the factors that influence it.

5. Law enforcement with prolegnas (Prolegnas is the abbreviation of Program Legislasi NasionalorNational Legislation Program) and judicial review, legislative review and so on.

Prolegnashereinafter is an integral part of the development of national law. Prolegnas is a planning instrument for the formation of a well-planned law or constitution, an integrated, systematic plan in accordance with the national development program, and also the development of community needs that includes both medium and long-term priority scales for the annual and annual term.Prolegnas became strategic in the development of national law, because from the perspective of planning,Prolegnas will describe the direction of legal development to be achieved for certain time scale such as long, medium orannual term arranged in a planned, integrated and systematic way by the Parliament and Government using certain indicators accordingly with the needs of national law and society. The preparation of Prolegnas is based on:[11]

a. The 1945 Constitution of the Republic of Indonesia;

b. People's Consultative Assembly Decree Order;

c. Other law orders;

d. National development planning system;

e. National RPJP;

f. RPJMN;

g. Government Work Plan (RKP) and DPR Strategic Plan; and

h. Aspirations and legal needs of the community.

In the DPR RI Regulation Number 2 of 2016 on Procedure of Preparation of Prolegnas, Article 6 asserts as follows:

(1) The Medium Term of Prolegnas shall be a Prolegnas period of 5 (five) years for 1 (one) term of membership of the People's Legislative Assembly.

(2) The Medium Term Prolegnas contains: a. an overview of national law; 
b. direction and policy of national legal development for 5 (five) years of membership of DPR;

c. the title of the draft law along with information on the draft law concepts covering:

1. background and purpose of compilation;

2. goals to be realized; and

3. range and direction of arrangement.

As a result, the Constitutional Court's decision clearly gives an impact on the preparation of Prolegnas especially related to the open cumulative list, which is the list of certain laws based on the needs and one of them is the result of the decision of the Constitutional Court. This indicates that the judicial review has implications for the politics of legislation. The Constitutional Court's decision to examine the law against the constitution gives implications on the politics of Indonesian law as well as implicate the agenda of enforcing the pillars of democracy and law enforcement.[7-p.423]

Political law of legislation, the establishment of law, and development plans of the country should be in harmony as a consequence of the legislation process. Besides, the process of formation of the Act is very unlikely to be separated from the democratization process; in this case, it absolutely is to provide guarantee and protection of human rights. Moreover, the idea of a legal state carries the consequence that the law is consciously made by the legislature. The formator of this law should adapt the long and medium term development planning documents in the National RPJP (RPJP is the abbreviation of Rencana Pembangunan Jangka Panjangor Long Term Development Plan) and RPJMN (RPJMN is abbreviation of Rencana Pembangunan Jangka MenengahDaerah which means Regional Medium Term Development Plan).Therefore it should be based on the existing Prolegnaswhich then will be reflected in the planning and political direction of legislation in Indonesia. It is becauseProlegnas contains a list of Draft Law (Draft), which is based on certain methods and parameters inspired by the vision and mission of the national law development. Based on data from Bappenas, so far the direction of regulatory policy is still not in line with the direction of national development planning. The conformity of the proposed bills in the RPJMN 2010-2014 with the proposals of 2010-2014 Prolegnas bills only contains 20 bills. This shows that conceptually the existence of Prolegnas as a planning in the field of legislation is ideal, but in the level of implementation it is not an easy thing to harmonize between the politics of legislation and national development planning in the RPJPN and RPJMN.[7 p.371372]

President Jokowi's government, althoughcontinues the work of the previous government, certainly has had a different policy from that of its predecessor. Initially in 2014, Jokowi's government continued the previous policy, and further changed it through Presidential Regulation number 2 in 2015 on RPJMN 2015-2019. The currentgovernment's vision is to achieve the realization of sovereignity, independence, and personality based on mutual cooperation. Efforts to realize this vision is through 7 Development Missions namely: (1) Realizing national security capable of maintaining regional sovereignty, sustaining economic independence by securing maritime resources, and reflecting the personality of Indonesia as an archipelagic country; (2) Realizing an advanced, sustainable, and democratic society based on the rules of law; (3) Realizing a free-active foreign policy and strengthening the identity as a maritime nation; (4) Actualizing the quality of human life of Indonesia to become high, advanced, and prosperous; (5) Actualizing a competitive nation; (6) Making Indonesia an independent, advanced, strong, and nation-based maritime state; (7) Realizing a society of personality in culture. Furthermore, the national development strategy, especially in relation to the stable social, political, legal and security conditions, is required as a prerequisite of quality development. The necessary conditions are: a. certainty and law enforcement; b. security and orderliness; c. politics and democracy; and d. managementand reformation of the bureaucracy. To show the priority in the path of change towards a politically sovereign Indonesia, independence in the economic field, and personality in culture, nine priority agendas are formulated. The nine priority agendas are called NAWA CITA, particularly in relation to strengthening the country's presence in reforming corruption, dignity, and trust-free system and law enforcement. National law development is a part of national development; thus it must be in line with national development priorities as well as the development of national law and ultimately must be reflected in the politics of national legislation.

\section{CONCLUSION}

National Law Development is a part of national development, that must be in line with national development priorities as well as the development of national law and ultimately must be reflected in the politics of national legislation. As a result of the Constitutional Court's verdict clearly impact on the preparation of Prolegnas especially related to the open cumulative list, the list of certain is laws based on the needs and one of them is the result of the decision of the Constitutional Court. This indicates that the judicial review has implications for the politics of legislation.

\section{REFERENCES}

[1] Jimly Asshiddiqie, 2006, Hukum Tata Negara dan Pilar-pilar Demokrasi, Konstitusi Press, Jakarta, p. 318.

[2] Ahmad Syahrizal, 2006, Peradilan Konstitusi, Suatu Studi tentang Adjudikasi Konstitusional Sebagai 
Mekanisme Penyelesaian Sengketa Normatif, Pradnya Paramita, Jakarta, p.263.

[3] Bambang Sutiyoso, Desember 2010, Pembentukan Mahkamah Konstitusi Sebagai Pelaku Kekuasaan Kehakiman di Indonesia, dalam Jurnal Konstitusi Volume 7 Nomor 6, Sekretariat Jenderal dan Kepaniteraan Mahkamah Konstitusi, Jakarta, p.29.

[4] Penjelasan Umum UU No. 17 Tahun 2007 tentang Rencana Pembangunan Jangka Panjang Nasional Tahun 2005-2025.

[5] Ahmad Ramli, "Membangun Hukum Nasional Yang Demokratis Serta Masyarakat Yang Berbudaya Dan Cerdas HUkum" dalam Buletin Hukum Perbankan dan Kebanksentralan, Vol. 6 No 2, Agustus 2008.
[6] Moh.Mahfud MD, 2010, Membangun Politik Hukum, Menegakkan Konstitusi, Raja Grafindo Persada, Jakarta, p.15-16.

[7] Riris Ardhanariswari, Dissertation in Padjajaran University,"Kewenangan Mahkamah Konstitusi Untuk Melakukan Pengujian Undang-Undang Terhadap Undang-Undang Dasar Dan Implikasinya Terhadap Pembangunan Hukum Nasional", 2013, p.362.

[8] The Bookhand of Regulation Structure Integration to the Government PlanWork, Directorate of Regulatory Analysis, National Development Planning Agencies, March 2013.

[9] The Construction of Constitution Regulation's Law number 12 at 2011 article 18. 